\title{
Righting and Remembering the Nazi Past: "Suppressed Music" in American Concert Performance
}

\section{LILY E. HIRSCH}

On October 4, 2012, in the audience at a "Recovered Voices" concert in Santa Monica, I found myself speaking to the individual sitting to my right, Louisa Saini. Before the concert began, I asked her about her attraction to the evening's event. She explained that she respected conductor James Conlon's reputation, enjoyed chamber music (the focus of the night), and wanted to take advantage of music so near her house. Still, she admitted very honestly that she was "a little uncomfortable" initially that night: she had overheard audience members discussing the composers' fates and their own Jewish histories. ${ }^{1}$ But why this discomfort? Did she feel that she somehow had no right to this concert, that this music was not her own? Was a Jewish identity or historical connection necessarily a part of the evening? Or was this discomfort generated by a clash of conscience-looking forward to the music while acknowledging its violent historical context?

Fast forward to July 11, 2013: in Tablet Magazine James Loeffler addressed performances devoted to the problematic term "Holocaust Music," concentrating on the activity of Murry Sidlin: "It may sound like heresy to criticize a pious act of Holocaust remembrance. But the true heresy is to turn Jewish composers into shadow images defined only by their status as Hitler's victims." ${ }^{2}$ Online reactions below Leoffler's article varied widely. A surprisingly unreflective response from the author of Virtually Jewish, Ruth Ellen Gruber, complained: "I don't understand his criticism-it smacks of 'oh, here is someone being praised, I guess I better shoot him down.”' Another poster, Nicole Maratovah Czarnecki, simply seemed stuck on the notion that work in this area is, yes, noble. She asked, "So, why on Earth, indeed, 'criticize a pious act'?" Is performance connected to the Holocaust so lofty, so personal, as to be beyond reproach?

I offer these two moments as my testament to the many issues evoked by the remarkably vibrant and wide-ranging arena of concertizing currently devoted to music denigrated during the Nazi era. These events arguably represent a powerful circumvention of controversy endemic in the creation of art after Auschwitz-related to the view that the experience of the Holocaust is unspeakable. ${ }^{3}$ To date, however, there has been no in-depth scholarly intervention into any aspect of this work. Given the literature limitations as well as the unwieldy reach of the topic, this article is necessarily a starting point-an initial

\footnotetext{
I would like to thank Michael Beckerman for his honest assessment of an earlier draft of this work. Thank you also to the Memorial Foundation for Jewish Culture for their generous support of this research.

${ }^{1}$ Louisa Saini, interview with the author (Santa Monica), October 4, 2012.

2 James Loeffler, "Why the New "Holocaust Music" is an Insult to Music_and the Victims of the Shoah," Tablet Magazine, July 11, 2013.

${ }^{3}$ For a provocative discussion of this idea in the evolving work of Theodor W. Adorno and Cathy Caruth, among others, see Thomas Trezise, Witnessing Witnessing: On the Reception of Holocaust Survivor Testimony (New York: Fordham University Press, 2013).
} 
look-confined to analysis of my collected data regarding the places, dates, and repertoire relevant to this realm of performance in the United States, despite its connections to similar and earlier work in other countries. Some early programs worth mentioning, related to varying degrees: the musicologist Anneliese Landau's "Forbidden Music" concerts in the United States during the 1940s, based in part on her work within Nazi Germany's Jewish Culture League (Jüdischer Kulturbund) ${ }^{4}$; and performances by survivors in Europe in the immediate aftermath of World War II, including Displaced Persons touring ensembles, such as the St. Ottilien Orchestra, as well as individual musicians, like Dutch-born singer and dancer Lin Jaldati (born Rebekka Brilleslijper) ${ }^{5}$ and Aleksander Kulisiewicz, who collected and performed the songs of concentration camp prisoners in the 1960s in Germany. ${ }^{6}$ More expansive initial projects of significance include, but are not limited to: the series Musica Viva, a title that first appeared in program pamphlets in September 1947, organized by the composer Karl Amadeus Hartmann in Munich (among the goals of the series was to "catch up" with works banned during the Third Reich)"; and the (West) Berlin Festival ("Berliner Festwochen") of September 1987, dedicated to "Verdraengte Musik: Berliner Komponisten im Exil"; "musica reanimata," officially the "Society for the Promotion and Re-discovery of Composers Persecuted by the Nazi Regime and Their Works," founded in Berlin in 1990; ; and Decca's Entartete Musik recordings, based in London. ${ }^{10}$ Performance related to music denigrated during the Nazi era has thus hardly been localized solely in the United States; it is a truly transnational enterprise with

\footnotetext{
${ }^{4}$ In 1941, Anneliese Landau submitted to the "B'nai B'rith Lodge" in Forest Hills, a suburb in New York, an outline for a program of "Forbidden Music." "Forbidden Music," advertised in one paper under the heading "The Nazis Banned Them" with photos of Landau and the participating singer Mascha Benya, who had previously worked with Landau in Berlin, featured the music of Jacques Offenbach, Giacomo Meyerbeer, Felix Mendelssohn, Ernest Bloch, Henryk Wieniawski, and Dmitri Shostakovich-Jewish and non-Jewish composers banned during the Third Reich-as well as national folk songs, among other works. Thank you to Bret Werb for supplying to the author a copy of a newspaper clip about Landau's work, held within the archives of the United States Holocaust Memorial Museum. For more information on Landau, see Lily E. Hirsch, A Fewish Orchestra in Nazi Germany: Musical Politics and the Berlin Fewish Culture League (Ann Arbor: University of Michigan Press, 2010). See also Anneliese Landau, "Forbidden Music," lecture, Akademie der Künste, Landau Archive 435; and "Forbidden Music," concert program, Akademie der Künste, Landau Archive 432. Thank you to Werner Grünzweig at the Akademie der Künste for supplying copies of these documents.

${ }^{5}$ Bret Werb, “Vu ahin zol ikh geyn?': Music Culture of Jewish Displaced Persons,” in Dislocated Memories: Fews, Music, and Postwar German Culture, ed. Tina Frühauf and Lily E. Hirsch (New York: Oxford University Press, 2014).

${ }^{6}$ See Barbara Milewski, "Remembering the Concentration Camps in East and West Germany: Aleksander Kulisiewicz and his Concerts of Prisoners' Songs," in Dislocated Memories: Fews, Music, and Postwar German Culture, ed. Tina Frühauf and Lily E. Hirsch (New York: Oxford University Press, 2014).

${ }^{7}$ But this intention had a decided orientation toward international and contemporary music. And much of this new music was programmed along with older related music in an effort to "create historical continuity through the juxtaposition of newer compositions with works from the Weimar period and beyond," while offering needed contextual support for the understanding of these newer works. This focus adhered to objectives of the occupying Allies, who held that concentration on modern and experimental music "would reestablish international communication and awareness, refamiliarize both the public and musical professionals with compositional techniques that had been banned by the Nazi Party, and inhibit all expressions of cultural uniformity and hegemony.” Alexander Rothe, "Rethinking Postwar History: Munich's Musica Viva during the Karl Amadeus Hartmann Years (1945-63)," Musical Quarterly 90/2 (2007), 231-32, 238, 242. These goals were similarly apparent in musical efforts in Darmstadt and Donaueschingen as well. See Amy C. Beal, "Negotiating Cultural Allies: American Music in Darmstadt, 1946-1956," Fournal of the American Musicological Society 53/1 (Spring 2000), 105-139. http://dx.doi.org/10.1525/jams.2000.53.1.03a00040.

${ }_{8}^{8}$ This project involved about twenty concerts and supported in performance composers such as Paul Dessau, Paul Ben-Haim, Paul Hindemith, Stefan Wolpe, Ernst Křenek, Kurt Weill, Arnold Schoenberg, Ernst Toch, Alexander von Zemlinsky, and Viktor Ullmann, among others.

${ }^{9}$ The group's initial work was the organization of concerts dedicated to the composers of Terezín. Since then, the group has expanded to support regular lecture recitals devoted to a variety of relevant topics, the organization of conferences, and the publication of scholarly material in a quarterly journal and series of books. See www.musica-reanimata.de.

${ }^{10}$ See http://www.deccaclassics.com/us/series/comp series?ID=ENTMUS. For discussing this history with me, I would like to thank the community involved in the "Suppressed Music" mailing list—especially Michael Haas, Albrecht Dümling, Joseph Toltz, and Amy Wlodarski.
} 
simultaneous physical and psychic connections to multiple countries. Yet, this article inevitably exposes uniquely American facets of this work by concentrating on its current manifestation in the United States.

With this focus, my aim is to explore the impulse to effect constructive change currently bolstering such music making. These diverse, yet conceptually positive goals, as I will show, help explain the myriad responses to and potential pitfalls within this work. By highlighting this opposition between noble intention and negative response or repercussion, this article contributes to a small, but growing, body of scholarship exposing the contradictions embedded in efforts to impact society constructively through music. ${ }^{11}$ Along these lines, I will raise questions about the role these performances play in a problematic conflation of Nazi-era composition and Jewish music.

\section{Why Recover Suppressed Music?}

To begin, let us define "suppressed music." This larger category often marks musical activity devoted to persecution during the Nazi era and is the title of a significant listserv dedicated to discussion and dissemination of relevant composition and performance. ${ }^{12}$ As outlined in a recent call for papers-for a conference in New Zealand entitled "Recovering Forbidden Voices: Responding to the Suppression of Music in World War Two" (August 22-25, 2014)—music suppressed during the Nazi era includes "music written in ghettos, concentration camps, and in exile, along with works classified and banned by the Nazis as 'Entartete Musik' [degenerate music]."13 Performances of "suppressed music" according to this definition can merge several different categories of music making, mixing music banned during the era as well as composers persecuted or forbidden at the time, and thus exiled, interned, or, in the case of some composers labeled "Entartete," long-deceased-a posthumous persecution. With this complex treatment, suppressed music is a "generic set," as David Levin and Ken Reinhard recognize, "unbranded" by any one "defining characteristic." 14

My representative sampling follows by necessity general use of this complicated category amalgamation (collected through Internet searches and review of news sources using key words within the New Zealand conference definition, and thus limited and no doubt skewed-though at least consistently-by the reach of cyberspace or accessible news media). Based on this data, which netted performances between the late 1980s through $2014,{ }^{15}$ concerts devoted to music suppressed during the Nazi era currently appear to be the regular work of an organized program or individual. To name a fewMichael Christie, James Conlon, Daniel Hope, Mina Miller, Nancy Rubenstein, Judith Sheridan, and

\footnotetext{
${ }^{11}$ See for example, Lily E. Hirsch, “Playing for Change': Peace, Universality, and the Street Performer," American Music 28, no. 3 (2010): 346-367, http://dx.doi.org/10.5406/americanmusic.28.3.0346; as well as work on benefit concerts or charity rock: David Crosby and David Bender, Stand and Be Counted: Making Music, Making History (San Francisco: Harper Collins, 2000), 48 and 53; Reebee Garofalo, Rockin' Out: Popular Music in the USA (Upper Saddle River, NJ: Pearson, 2005), 312-315; Kip Pegley and Susan Fast, “America: A Tribute to Heroes': Music, Mourning, and the Unified American Community,” in Music in the Post-9/11 World, ed. Jonathan Ritter, J. Martin Daughtry (New York: Routledge, 2007); Sam O'Connell, "Which Music for Which Catastrophe?: The Functions of Popular Music Twenty-First Century Benefit Concerts," in Popular Music and Human Rights, vol. 1: British and American Music, ed. Ian Peddie (England: Ashgate, 2011).

${ }^{12}$ See https://www.jiscmail.ac.uk/cgi-bin/webadmin?SHOWTPL=HELP-SUBEDIT\&L=SUPPRESSED-MUSIC.

${ }^{13}$ See http://www.nzsm.ac.nz/events/conferences-and-seminars/mww2.

${ }^{14}$ David J. Levin and Kenneth Reinhard, “A Note from the Editors,” Opera Quarterly 29, no. 1 (2013), 1-5. http://dx.doi.org/10.1093/oq/kbt014.

${ }^{15}$ One of the earliest of these concerts, entitled "Composers of the Holocaust," took place on January 28, 1989, at the EmanuEl Midtown Y in New York. It was organized by the artistic director of Downtown Music Productions, Mimi Stern-Wolfe. As Stern-Wolfe recalls, "As far as we knew, very little of all this was known to American audiences.” Mimi Stern-Wolfe, email to the author, August 28, 2013.
} 
Marshall Taylor. Like all concert organizers, these individuals and others involved mediate a variety of social forces. As William Weber observes, "Because most concerts serve a variety of groups with different tastes, desires, and needs, planning a program is a kind of political process." ${ }^{16}$ This process necessitates a balance between artistic integrity or mission and self-preservation, a response to market forces. Such response, for some, lies in the intersection between commerce and art. As conductor Leonard Slatkin explains, "In depressed economies, you must convince reluctant donors to contribute even more money by emphasizing the value of your product to the community." ${ }^{17}$ The nexus of negotiation in concert organization links concerts devoted to music denigrated during the Nazi era with any other musical program. However, concerts of suppressed music can be distinguished by the pronounced specifics of their intention to impact society constructively through music. For evidence of this impulse, I turn to displayed intention in program titles as well as public utterance-all products of mediation and thereby a unique reflection of this political process.

First and foremost, titles often feature "re"-the prefix of return, again. We see this trend in prominent use of the terms "rediscovered" and "recovering" or "recovered" (see Example 1). This word choice points to the goal of revival, defined by ethnomusicologist Tamara Livingston as "social movements which strive to 'restore' a musical system believed to be disappearing or completely relegated to the past for the benefit of contemporary society." 18 James Conlon's project, "Recovered Voices," at Los Angeles Opera, a prominent and influential case in point, fits decidedly into this category, especially given its framing in public explanation. In the online "Welcome," on The OREL site connected to "Recovered Voices," musicologist Michael Beckerman insists, "Our goal is neither to write eulogies nor to create narratives or 'spins' concerning the material we present." 19 In this way, The OREL Foundation contributes to what Beckerman terms a "dynamic revival." Conlon himself favors wording highlighting the recovery of a loss and similarly avoids ties to memorialization. In an interview, he explained, "I'm not in the business of memorialization, however noble that is." ${ }^{20}$ Rather, he seeks to mend the perceived German canon, despite recent challenges to this ideal, ${ }^{21}$ repairing the "greatest single rupture in what had been a centuries-long stream of German classical music." 22 This musical recovery, according to Conlon, makes possible a fuller appreciation of a supposed American musical style. He writes, "Further, our own American heritage owes an enormous debt to those who emigrated to Hollywood and Broadway, bringing their distinctive personalities with them, and creating a style that has since evolved into a distinctly American one." 23

\footnotetext{
${ }^{16}$ William Weber, The Great Transformation of Musical Tastes: Concert Programming from Haydn to Brahms (Cambridge: Cambridge University Press, 2008), 1.

${ }^{17}$ Leonard Slatkin, Conducting Business: Unveiling the Mystery Behind the Maestro (Milwaukee, WI: Amadeus Press, 2012 ), 124.

${ }^{18}$ Tamara E. Livingston, “Music Revivals: Towards a General Theory,” Ethnomusicology 43, no. 1 (1999), 66. http://dx.doi.org/10.2307/852694.

${ }^{19}$ See http://orelfoundation.org/index.php/pages/orelFoundation/.

${ }^{20}$ Naomi Pfefferman, “Opera: Restoring Nazi-Suppressed 'Recovered Voices,"” The Fewish Observer, February 14, 2008.

${ }^{21}$ Robert Fink, "Elvis Everywhere: Musicology and Popular Music Studies at the Twilight of the Canon," American Music (Summer 1998), 141. http://dx.doi.org/10.2307/3052563.

22 "LA Opera Celebrates Nazi-Repressed Composers," All Things Considered, NPR, March 7, 2007. Conlon wrote similar sentiments in his most complete public explanation of his musical recovery. James Conlon, "Recovering a Musical Heritage: The Music Suppressed by the Third Reich," http://www.jamesconlon.com/index new.php?/about/writing detail/recovering a musical heritage the music suppressed by the third_reich. (This statement is also available on the OREL site.)

${ }^{23}$ Conlon, "Recovering a Musical Heritage."
} 


\begin{tabular}{|c|c|c|c|c|}
\hline Title & Date & Place & Performer(s) & Repertoire \\
\hline $\begin{array}{l}\text { "Ervin Schulhoff } \\
\text { Rediscovered" }\end{array}$ & $\begin{array}{l}\text { January 24, } \\
1994\end{array}$ & $\begin{array}{l}\text { Merkin Hall, } \\
\text { New York, NY }\end{array}$ & $\begin{array}{l}\text { Mimi Stern-Wolf, } \\
\text { Downtown Music } \\
\text { Productions, }\end{array}$ & Schulhoff \\
\hline $\begin{array}{l}\text { "Recovering a } \\
\text { Musical Heritage" }\end{array}$ & March 2003 & $\begin{array}{l}\text { New York City, } \\
\text { NY }\end{array}$ & James Conlon & $\begin{array}{l}\text { Schulhoff, Haas, Klein, } \\
\text { Krása, Bartók, Weill, and } \\
\text { Zemlinsky }\end{array}$ \\
\hline "Recovered Voices" & $\begin{array}{l}\text { March 7, 10, } \\
2007\end{array}$ & LA Opera, CA & James Conlon, LA Opera & $\begin{array}{l}\text { Schreker, Braunfels, } \\
\text { Křneke, Ullmann, } \\
\text { Korngold, Zemlinsky, } \\
\text { and Schulhoff }\end{array}$ \\
\hline $\begin{array}{l}\text { "Recovered Voices: } \\
\text { Enduring } \\
\text { Masterworks of } \\
\text { Composers Almost } \\
\text { Silenced by the } \\
\text { Nazis" }\end{array}$ & $\begin{array}{l}\text { January 20, } \\
2010\end{array}$ & $\begin{array}{l}\text { Syracuse } \\
\text { University, NY }\end{array}$ & $\begin{array}{l}\text { Syracuse Symphony } \\
\text { Orchestra (SSO), the SU } \\
\text { Oratorio Society, and the } \\
\text { Syracuse International } \\
\text { Film Festival }\end{array}$ & $\begin{array}{l}\text { Ravel, Schrecker, } \\
\text { Schulhoff, and } \\
\text { Zemlinsky }\end{array}$ \\
\hline $\begin{array}{l}\text { "Rediscovered } \\
\text { Masters" }\end{array}$ & $\begin{array}{l}\text { October 7-9, } \\
2010\end{array}$ & $\begin{array}{l}\text { Symphony Hall, } \\
\text { Phoenix, AZ }\end{array}$ & Phoenix Symphony & $\begin{array}{l}\text { Krása, Weinberg, and } \\
\text { Prokofiev }\end{array}$ \\
\hline $\begin{array}{l}\text { "Rediscovered } \\
\text { Beauty: Suppressed } \\
\text { Composers" }\end{array}$ & $\begin{array}{l}\text { March 18, } \\
2011\end{array}$ & $\begin{array}{l}\text { Daniel Recital } \\
\text { Hall at Cal State } \\
\text { Long Beach, CA }\end{array}$ & $\begin{array}{l}\text { Ryan Ross and the Cole } \\
\text { Conservatory at CSULB }\end{array}$ & $\begin{array}{l}\text { Klein, Ullmann, a set of } \\
\text { Yiddish songs, Krása, and } \\
\text { Schulhoff }\end{array}$ \\
\hline $\begin{array}{l}\text { "Rediscovered } \\
\text { Masters" }\end{array}$ & $\begin{array}{l}\text { July 7, 8, and } \\
27,2011\end{array}$ & $\begin{array}{l}\text { Chautauqua } \\
\text { Auditorium, } \\
\text { Boulder, CO }\end{array}$ & $\begin{array}{l}\text { Michael Christie, } \\
\text { Colorado Music Festival } \\
\text { Orchestra }\end{array}$ & $\begin{array}{l}\text { Korngold, Weinberg, and } \\
\text { Gorecki }\end{array}$ \\
\hline
\end{tabular}

Example 1: A Sampling of "Re"

For Conlon, such benefit to contemporary society ultimately ensures a sort of posthumous justice. In an NPR interview, he explained: "You cannot undo the injustice of the lost lives[,] of the cruelty. But in the case of the composers you can do the one thing that would have meant the most to them, which is to perform their music." ${ }^{24}$ Conlon, a Roman Catholic, in this way arguably corresponds to the American image of the heroic Gentile. As Tim Cole observes, referencing the main character in Steven Spielberg's film Schindler's List (1993), "In American tellings of the 'Holocaust' it is either the liberating American Army who are the heroes-the portrayal favoured at the United States Holocaust Memorial Museum—or Righteous Gentiles-the portrayal favoured by Spielberg." 25

But this pursuit of justice, whether American or not, seems to move beyond Conlon's aspirations in other programs devoted to this repertoire-programs that seem to suggest in title wording that undoing death is in a way possible. In concerts of suppressed music, reference to some sort of void-silence, darkness, suppression—off-sets imagery related to life or rebirth—-reborn," "life," or "live(s)" (see Examples 2 and 3).

\footnotetext{
${ }^{24}$ David Mermelstein, "New Life for Works Hitler Tried to Kill,” New York Times, February 10, 2008, http://www.nytimes.com/2008/02/10/arts/music/10merm.html? pagewanted=all\& $\mathrm{r}=0$.

${ }^{25}$ Tim Cole, Selling the Holocaust: From Auschwitz to Schindler, How History is Bought, Packaged, and Sold (NY: Routledge, 1999), 82.
} 


\begin{tabular}{|c|c|c|c|c|}
\hline $\begin{array}{l}\text { "Silent Voices, the } \\
\text { Artists of Terezín" }\end{array}$ & April 18, 1993 & $\begin{array}{l}\text { Merkin Concert } \\
\text { Hall, New York, } \\
\text { NY }\end{array}$ & $\begin{array}{l}\text { Mark Luwig, Terezín } \\
\text { Chamber Music } \\
\text { Foundation, and the } \\
\text { Hawthorne Quartet }\end{array}$ & $\begin{array}{l}\text { Klein, Krása, Ullmann, } \\
\text { Haas, and Schulhoff }\end{array}$ \\
\hline $\begin{array}{l}\text { "Entartete Musik-- } \\
\text { Music Suppressed } \\
\text { by the Nazi } \\
\text { Regime" }\end{array}$ & $\begin{array}{l}\text { November 9, } \\
2003\end{array}$ & $\begin{array}{l}\text { Temple Beth } \\
\text { Israel, 10462 } \\
\text { North 56th Street } \\
\text { in Scottsdale, AZ }\end{array}$ & Musica Nova & $\begin{array}{l}\text { Schreker, Humperdinck, } \\
\text { Korngold, Mahler, and } \\
\text { Mendelssohn }\end{array}$ \\
\hline $\begin{array}{l}\text { "Forbidden Sights } \\
\text { and Sounds: Nazi } \\
\text { Suppression of Art } \\
\text { and Culture" }\end{array}$ & June 2004 & $\begin{array}{l}\text { Cincinnati Art } \\
\text { Museum, OH }\end{array}$ & $\begin{array}{l}\text { University of Cincinnati } \\
\text { College-Conservatory of } \\
\text { Music }\end{array}$ & $\begin{array}{l}\text { Klein, Schulhoff, } \\
\text { Schoenberg, Grosz, and } \\
\text { Strayhorn }\end{array}$ \\
\hline $\begin{array}{l}\text { "Out of Darkness: } \\
\text { Music from } \\
\text { Terezin," } \\
\text { Greenwich Music } \\
\text { Festival }\end{array}$ & $\begin{array}{l}\text { June } 10,12, \\
14,2009\end{array}$ & $\begin{array}{l}\text { The Theater at } \\
\text { St. Catherine of } \\
\text { Siena, Riverside, } \\
\text { NY }\end{array}$ & $\begin{array}{l}\text { ICE and young stars } \\
\text { from the Metropolitan } \\
\text { Opera, New York City } \\
\text { Opera, Opera Australia, } \\
\text { and La Scala }\end{array}$ & Ullmann \\
\hline $\begin{array}{l}\text { "Silenced but not } \\
\text { Forgotten" }\end{array}$ & April 6, 2013 & $\begin{array}{l}\text { University of } \\
\text { California, Irvine, } \\
\text { CA }\end{array}$ & $\begin{array}{l}\text { Pianist Nina Scolnik and } \\
\text { the Angeles Quartet, } \\
\text { among others }\end{array}$ & $\begin{array}{l}\text { Mendelssohn, Schreker, } \\
\text { Klein, Korngold, and } \\
\text { Shostakovich }\end{array}$ \\
\hline
\end{tabular}

Example 2: A Sampling of Darkness, Silence, and/or Suppression

\begin{tabular}{|c|c|c|c|c|}
\hline "Music Reborn" & October 26,2006 & $\begin{array}{l}\text { Rodef Shalom } \\
\text { Congregation in } \\
\text { Shadyside, } \\
\text { Pittsburgh, PA }\end{array}$ & $\begin{array}{l}\text { Jason Calloway and } \\
\text { Nancy Rubenstein }\end{array}$ & $\begin{array}{l}\text { Zeisl, Schulhoff, and } \\
\text { Castelnuovo-Tedesco }\end{array}$ \\
\hline $\begin{array}{l}\text { "Music Reborn: } \\
\text { Forbidden and } \\
\text { Forgotten" }\end{array}$ & October 25, 2009 & $\begin{array}{l}\text { Carol Ann } \\
\text { Reichgut Concert } \\
\text { Hall in Seton Hill } \\
\text { University's } \\
\text { Performing Arts } \\
\text { Center, } \\
\text { Greensburg, PA }\end{array}$ & & Schulhoff and Ullmann \\
\hline $\begin{array}{l}\text { "Will To Create, } \\
\text { Will to Live: The } \\
\text { Music of Terezín" }\end{array}$ & $\begin{array}{l}\text { January 17, 19, } \\
2012\end{array}$ & $\begin{array}{l}\text { Lexington Avenue, } \\
\text { New York, NY }\end{array}$ & Nach Ensemble & $\begin{array}{l}\text { Domažlický, I. Weber, A. } \\
\text { Strauss, Taube, Klein, } \\
\text { Schul, Ullmann, Krása, } \\
\text { Śvenk, Skutečky, and } \\
\text { Anonymous }\end{array}$ \\
\hline $\begin{array}{l}\text { "And Their Music } \\
\text { Lives On" }\end{array}$ & May 29, 2012 & $\begin{array}{l}\text { Virginia Holocaust } \\
\text { Museum in } \\
\text { Richmond, VA }\end{array}$ & $\begin{array}{l}\text { Richmond } \\
\text { Symphony } \\
\text { Orchestra }\end{array}$ & $\begin{array}{l}\text { Messiaen, Singaglia, and } \\
\text { Milhaud }\end{array}$ \\
\hline $\begin{array}{l}\text { "And Their Music } \\
\text { Lives On: } \\
\text { Works of the } \\
\text { Holocaust } \\
\text { Generation" }\end{array}$ & May 8, 2013 & $\begin{array}{l}\text { Robin Hixon } \\
\text { Theater, Clay and } \\
\text { Jay Barr Education } \\
\text { Center, Norfolk, } \\
\text { VA }\end{array}$ & $\begin{array}{l}\text { Jocelyn Adelman } \\
\text { and } \\
\text { Amanda Halstead }\end{array}$ & $\begin{array}{l}\text { Zemlinsky, Křenek, and } \\
\text { Messiaen }\end{array}$ \\
\hline
\end{tabular}

Example 3: A Sampling of "Reborn," "Life," or "Live(s)" 
This dichotomy of dark and light is complementary in theories of rebirth, allied with revival in one of its earliest musical applications in the work of English folk song collector Cecil Sharp. (Cecil Sharp in his work with the English folk song spoke of both revival and a hope that English music would be "reborn." ${ }^{26}$ Defined as both reincarnation as well as "the process of being born again during life," ${ }^{27}$ rebirth in either conception is contingent on a form of survival-a confrontation with darkness, injustice, and/or death. ${ }^{28}$ This confrontation too has particular resonance in America's relationship to the Holocaust. After the Holocaust, the notion of rebirth, darkness to light, related to classic myths of salvation, held a specific place in American Jewish thinking about Israel. Richard L. Rubenstein explains, "Death and rebirth are the great moments of religious experience. In the twentieth century the Jewish phoenix has known both ... Death in Europe was followed by resurrection in our ancestral home." ${ }^{29}$ This redemptive coloring also operated and continues to operate in American responses to the Holocaust more generally. What many scholars have observed as the Americanization of the Holocaust privileges stories of redemption in tolerance, pluralism, and human rights—all themes significant to the construction of American identity. ${ }^{30}$ Romantic thinking about music resonates significantly with these American conceptions of survival and rebirth after the Holocaust. As Hegel proclaimed in lectures during the 1820s, music is "the art of the soul," a subjective art "directly addressed to the soul." ${ }^{11}$ Through music, a composer-his or her soulcould thereby live on after death, reborn in concert.

Contrasting this goal of musical restoration and posthumous justice, other projects and concerts emphasize terms such as "memory" or "remembering" and "remembrance," which point to efforts of memorialization and "commemoration" (see Example 4). Mina Miller's Music of Remembrance (MOR) in Seattle is a significant example of this latter aim. Devoted to "remembering Holocaust musicians and their art," ${ }^{32}$ the group's concerts of suppressed music as well as new work associated with the Holocaust annually mark the anniversary of Kristallnacht in the fall and Holocaust Remembrance Day each spring. ${ }^{33}$ With this emphasis, MOR is explicitly aimed at remembrance, and thus most closely operates within memory work-making the past present. The means of this pastness in the present is commemoration, a complex, symbolic act of collective memory transmission, which, according to historian Geoffrey Cubitt, contributes "distinctively, and in many social settings vitally, to making the past an active rather than a merely passive element in people's social awareness." ${ }^{34}$ Such activity also represents, in the estimation of Anita Kasabova, scholar of philosophy, a way "to account for unimaginable events caused by our species." 35 Both conceptions of memory's work index education, promoting understanding through remembrance.

\footnotetext{
${ }^{26}$ See Neil V. Rosenberg, Introduction, Transforming Tradition: Folk Music Revivals Examined (Urbana: University of Illinois Press, 1993), 17.

${ }^{27}$ See W.H.R. Rivers, "Presidential Address: The Symbolism of Rebirth," Folklore 33, no. 1 (March 31, 1922 ), 21. http://dx.doi.org/10.1080/0015587X.1922.9719219.

${ }^{28}$ Huston Smith, "Karma, Rebirth, and Free Will," in Reincarnation: The Phoenix Fire Mystery, ed. Joseph Head and S.L. Cranston (New York: Julian Press/Crown Publishers, Inc., 1977), 8 and 11.

${ }^{29}$ Quoted in Jacob Neusner, "The Implications of the Holocaust,” The Fournal of Religion 53, no. 3 (July 1973 ), 300. http://dx.doi.org/10.1086/486348.

${ }^{30}$ Cole, Selling the Holocaust, 82.

${ }^{31}$ These lectures were published posthumously in 1835. G.W.F. Hegel, Aesthetics: Lectures on Fine Art, vol. 2, trans. T.M.

Knox, (Oxford: Clarendon Press, 1975), 891. http://dx.doi.org/10.1093/actrade/9780198244998.book.1.

${ }^{32}$ See http://www.musicofremembrance.org/ musicofr/page/mission-statement.

${ }^{33}$ I should say, I included in my collected data only MOR events that had a definite focus on works suppressed during the Nazi era rather than newly composed music, which, while an intriguing area of music making, is not the focus of the present study.

${ }^{34}$ See Geoffrey Cubitt, History and Memory (Manchester: Manchester University Press, 2007), 219.

${ }^{35}$ Anita Kasabova, "Memory, Memorials, and Commemoration," History and Theory 47 (October 2008), 332.
} 


\begin{tabular}{|l|l|l|l|l|}
\hline $\begin{array}{l}\text { "Remembering the } \\
\text { Colocaust }\end{array}$ & $\begin{array}{l}\text { February 26, } \\
\text { Concert" }\end{array}$ & Azusa, CA & $\begin{array}{l}\text { Music ensembles of } \\
\text { Azusa Pacific University }\end{array}$ & \\
\hline $\begin{array}{l}\text { "Music at the Edge } \\
\text { of Life: In } \\
\text { Remembrance of }\end{array}$ & April 10,2010 & Santa Rosa, CA & $\begin{array}{l}\text { Santa Rosa Symphony } \\
\text { Chamber Players }\end{array}$ & $\begin{array}{l}\text { Haas, Schulhoff, } \\
\text { Krása, and } \\
\text { Ullmann }\end{array}$ \\
$\begin{array}{l}\text { Who Perished in } \\
\text { the Holocaust" } \\
\text { "A Place and a } \\
\text { Name: } \\
\text { Remembering the } \\
\text { Holocaust" }\end{array}$ & $\begin{array}{l}\text { November 13, } \\
\text { "Music and } \\
\text { Memory" }\end{array}$ & $\begin{array}{l}\text { Curtis Institute, } \\
\text { Philadelphia, PA }\end{array}$ & Dolce Suono & $\begin{array}{l}\text { Ulmann, Previn, Weber, } \\
\text { Avni, Klein, and Ran }\end{array}$ \\
$\begin{array}{l}\text { "Music of } \\
\text { Commemoration" }\end{array}$ & April 22, 2012 & $\begin{array}{l}\text { Agudas Achim } \\
\text { Congregation, } \\
\text { Iowa City, IA }\end{array}$ & $\begin{array}{l}\text { Alan Huckleberry, } \\
\text { among others }\end{array}$ & $\begin{array}{l}\text { Haas, Schulhoff, and } \\
\text { Ullmann }\end{array}$ \\
\hline $\begin{array}{l}\text { "Holocaust } \\
\text { Remembrance } \\
\text { Concert" }\end{array}$ & 2013 & $\begin{array}{l}\text { Hebrew Union } \\
\text { College, } \\
\text { Cincinnati, OH }\end{array}$ & James Tocco & $\begin{array}{l}\text { Schulhoff, Shostakovich, } \\
\text { and Ullman }\end{array}$ \\
\hline
\end{tabular}

Example 4: A Sampling of "Memory," Remembering/Remembrance, or "Commemoration"

Miller emphasized the importance of this aspect of her remembrance-her program operating as a sort of retrospective benefit concert series-in remarks opening MOR's sixteenth season: "Through music, Music of Remembrance strives to broaden everyone's understanding of the Holocaust's many dimensions, and to make clear its significance for all of humanity." ${ }^{36}$ In a documentary chronicling MOR's first decade of work, entitled Unsilenced, Miller connects this mission to her own history, the family she lost in the Holocaust. Through her concerts as well as more explicit efforts of education, such as events in schools, Miller shares "her story." 37

I should mention that MOR's aims, like Conlon's intended goals, are not restricted to a single notion of the positive work music can serve in concert. In addition to a primary focus on remembrance, the MOR mission statement reads, "It is a priceless gift that much of this music has survived as moral and artistic defiance in the face of catastrophe. We must ensure that these voices of musical witness be heard.” This emphasis on a moral imperative helps situate MOR and its goals within the realm of revival as well. Though commemoration and revival represent two different impulses, in concertizing devoted to music banned by the Nazis these goals can coexist or at least exist side by side to varying degrees. ${ }^{38}$

With aspirations to right and/or remember past wrongs, these illustrative programs aim to perform a particular good within society, nuancing the negotiation inherent in the organizing of any concert. And I would argue that the specific repertoire of concerts devoted to suppressed music within my sampling confirms these aims more generally. The popularity in particular of Erwin Schulhoff and Viktor Ullmann (the two composers most often performed at these events) is proof: both composers work within efforts of

${ }^{36}$ See http://www.musicofremembrance.org/ musicofr/about/minas-corner.

${ }^{37}$ See John Sharify, Unsilenced: Music of Remembrance's First Decade of Musical Witness, documentary film, Music of Remembrance, 2009.

${ }^{38}$ See http://www.musicofremembrance.org/ musicofr/page/mission-statement. There is a similar coexistence in the goals of the Terezín Music Foundation, which, since 1991, has worked to recover, preserve, and perform works created by prisoners in Terezín, while also fulfilling "their unrealized artistic and mentoring roles with new commissions by emerging composers," then performed as an "enduring memorial." See http://www.terezinmusic.org/mission-history.html. 
rebirth, recovery, or rediscovery, and thus revival, given the fascination with the composers' musical mastery and changing styles (the music itself). They also operate effectively in events focused more directly on death and therefore memory and commemoration, with their respective deaths in concentrations camps (there is of course much more to be said in this regard). ${ }^{39}$ But the aims sustaining performances of music denigrated during the Third Reich also implicate competing agendas as well as concerns about the ethics of Holocaust representation-all of which can undermine or at least muddy positive intentions.

\section{Uncovering Recovery's Repercussions}

Concerts of suppressed music, especially those featuring artists with little name recognition outside of this area of music making, arguably benefit organizers, offering a platform and visibility founded on the tragedy of others. Programs that openly integrate fundraising invite further skepticism along these lines while, at the same time, underscoring the marketability of the Nazi era (the Holocaust sells, after all). In addition to charges of opportunism or exploitation, hardly new, performances of music denigrated during the Nazi era navigate to varying degrees a precarious balance between music aesthetics and history. Privileging of the music_its worth above all_can invite charges founded in the ethics of Holocaust representation. The revivalist effort to repair a musical rupture and maintain historical continuity arguably conceals trauma, akin to what German studies scholar Eric Santner calls "narrative fetishism." ${ }^{40}$ This charge similarly effects invocations of rebirth, which can hide victimization through focus on survival, as author of Traumatic Realism, Michael Rothberg, argues in his discussion of the movie Schindler's List. ${ }^{41}$

On the other hand, spotlighting the past in commemoration-the disproportionate reliance on the history of the Nazi era-can lead to one-dimensional readings of the composers concerned-their individual biographies, musical styles, and repertoire subsumed by a larger association with the Holocaust. Within concerts of suppressed music (titles, advertisements, or program notes), the terms "Holocaust musician" and "Holocaust composer" (any grouping of people within a category of "the Holocaust") further work to conceal the distinctive features of the music and composers involved (see Example 5). Even if we ascribe to this category only music composed within a concentration camp (setting aside the work of composers such as Zemlinsky who actually emigrated in 1938 and subsequently died in 1942 in New York), we, as James Loeffler has recently argued, "severely restrict the rich meanings in and around [these works]." To hear this music, as Loeffler makes clear in his work on Soviet music, "we must first start by asking what we gain, and what we lose, in applying our cultural labels to their historical music." 42 Ernst Křenek underscored the complexities of his own output and biography in rare direct response to

\footnotetext{
39 These composers were the focus of a recent conference, with an overview on the OREL site by Juliane Brand, entitled, "Reimagining Erwin Schulhoff, Viktor Ullmann and the German-Jewish-Czech World: A Conference Overview." For useful reviews exposing this interest in the composers' evolving musical styles and biographies, see, for example: Jeremy Eichler, "Music Silenced by the Nazis Finds Its Voice," New York Times, April 30, 2004, E1; Anne Midgette, "Surfacing the Forgotten Music of Ernst Křenek," New York Times, May 6, 2004; and Allan Kozinn, “Oppressor's Tale, Written in Oppression,” New York Times, February 3, 2011, C1.

${ }^{40}$ Eric Santner, "History beyond the Pleasure Principle: Some Thoughts on the Representation of Trauma," in Stranded Objects: Mourning, Memory, and Film in Postwar Germany, ed. Saul Friedlander (Ithaca, NY: Cornell University Press, 1990), $143-54$.

${ }^{41}$ Michael Rothberg, Traumatic Realism: The Demands of Holocaust Representation (Minneapolis: University of Minnesota Press, 2000), 243.

${ }^{42}$ James Loeffler, “'In Memory of Our Murdered (Jewish) Children': Hearing the Holocaust in Soviet Jewish Culture,” Slavic Review 73, no. 3 (Fall 2014), 611.
} 
similar labeling, in this case the historical designation "degenerate music" in the Los Angeles Philharmonic's titling of a 1991 event honoring his birthday: "I fail to see what my $90^{\text {th }}$ birthday has to do with 'entartete Kunst' (degenerate art). If I should be associated therewith at all, it would seem to be more logical to select a work from the early 20s ... instead of the 'Symphonic Elegy' which I wrote in this country after that obnoxious concept had long become obsolete." ${ }^{43}$ Performances of music denigrated during the Nazi era are thus inherently a "gray zone," one in which I myself entered, as Mike Beckerman reminded me, in the very writing of this article. Am I somehow complicit in the violence of the Holocaust when I write about it?

\begin{tabular}{|l|l|l|l|l|}
\hline $\begin{array}{l}\text { "Hope Survives: } \\
\text { The Lost } \\
\begin{array}{l}\text { Goneration of } \\
\text { Compost }\end{array}\end{array}$ & March 25, 2012 & $\begin{array}{l}\text { The Amado Recital } \\
\text { Hall, 34th and } \\
\text { Spruce Streets, } \\
\text { University of } \\
\text { Pennsylvania, PA }\end{array}$ & The Meiravi Quartet & $\begin{array}{l}\text { Ullmann, Schulhoff, } \\
\text { Krása, Zemlinsky, } \\
\text { among others }\end{array}$ \\
\hline $\begin{array}{l}\text { "And Their Music } \\
\text { Lives On: } \\
\begin{array}{l}\text { Works of the } \\
\text { Gelocaust }\end{array}\end{array}$ & May 8,2013 & $\begin{array}{l}\text { Robin Hixon } \\
\text { Theater, Clay and } \\
\text { Jay Barr Education } \\
\text { Center, Norfolk, VA }\end{array}$ & $\begin{array}{l}\text { Jocelyn Adelman } \\
\text { and } \\
\text { Amanda Halstead }\end{array}$ & $\begin{array}{l}\text { Zemlinsky, Křenek, and } \\
\text { Messiaen }\end{array}$ \\
\hline
\end{tabular}

Example 5: A Sampling of "the Holocaust" in Title Wording

On top of this unstable terrain I would like to add consideration of what I read as a misleading correlation within some concertizing of suppressed music between the Holocaust and Jewish music. This final issue has to do with a confirmed, but also assumed Jewishness, so to speak, in concert focus, geography, and venue. First, concert focus: though not all composers persecuted during the Third Reich were Jewish, by Hitler's estimation or their own, many programs in this realm of music making specifically highlight Jewish composers or music. To point out but a few examples, Judith Sheridan's "Forbidden Voices" features "songs by Jewish composers which were banned by Nazis in the 1930s"; a concert on April 10, 2010, in Santa Rosa, California, was titled "Music at the Edge of Life: In Remembrance of Jewish Composers Who Perished in the Holocaust"; Michael Christie's "Rediscovered Masters" concerts of July 7, 8, and 27, 2011, honored "the music of Jewish composers who were silenced during World War II." Second, spatial spread and venue: to date, programs of music denigrated during the Nazi era have appeared in at least twenty-two different states, pointing to strong interest in the Holocaust throughout the United States. Such interest is bolstered by the celebratory role the Nazi era plays in the American self-image ${ }^{44}$ as well as the power of dark tourism. ${ }^{45}$ But the popularity of these performances in New York, Arizona, and, above all, California (especially southern California) clearly reveals a Jewish connection (Los Angeles, of course also the eventual home of many émigré composers, now boasts the

\footnotetext{
${ }^{43}$ Quoted in Martin Bernheimer, “A Beguiling, Belated Salute to Ernst Křenek,” Los Angeles Times, March $20,1991$.

${ }^{44}$ Cole, Selling the Holocaust, 155.

${ }^{45}$ Philip R. Stone, "Dark Tourism and the Cadaveric Carnival: Mediating Life and Death Narratives at Gunther von Hagens' Body Worlds," Current Issues in Tourism 14, no. 7 (2011), 686.
} 
fourth largest Jewish population in the world, behind New York City, Tel Aviv, and Jerusalem). ${ }^{46}$ This, albeit brief, explanation of concert geography is confirmed by regular use of Jewish spaces as performance venues: synagogues or, in the case of the April 17, 2012, concert of Ullmann's music, centers for Jewish learning, such as Chicago's Spertus.

Given these explicit Jewish connections, it may come as no surprise that there can be assumptions of Jewishness attached to programs that lack a singular focus on a supposed Jewish repertoire-an example, "Recovered Voices." Conlon's program actively avoids formal circumscription of its repertoire as Jewish given what Christopher Koelsch, CEO of LA Opera, views as a potential danger of re-ghettoizing the music and composers involved. ${ }^{47}$ The San Francisco Classical Voice nonetheless described Conlon's project under the heading "Conlon to Direct Jewish Music Project." 48 Similarly, Naomi Pfefferman in the Jewish Observer article "The Best of (Jewish) Los Angeles 2008" included "Recovered Voices" under the category "Best Places to See Jewish Opera," again labeling the project Jewish. ${ }^{4950}$

Such association, confirmed or assumed, has a contextual foundation in part in a history of investment in the Holocaust within American Jewish communities. This investment has been and still is tied directly to self-identification as Jewish in the United States. In 1999, Peter Novick in fact recognized a potential fate in the Holocaust as the sole common link between American Jews. ${ }^{51}$ But this tie also relates to broader treatments of Jewish music today, channeling the ongoing problem of defining Jewish music. In "What is Jewish Music?" sponsored by the Jewish Virtual Library ("excerpted from the Jewish Music Institute in London"), Jewish music is today assigned several categories: Ashkenazi Music (Klezmer), Sephardi Music, Israeli Music, Synagogue Music, Western Classical Music, and Suppressed Music. ${ }^{52}$ Similarly, the ethnomusicologist Jeff Janeczko, based on his work on contemporary secular Jewish music in America, identifies "unconscious assumptions about what could be admitted into a canon of

\footnotetext{
${ }^{46}$ This Jewish involvement in Los Angeles is increasingly diverse, with the settlement of Sephardic Jews from Algeria, Rhodes, and the Levant, as well as Jews released from the Soviet Union and pushed from Iran. Karen S. Wilson, "Introduction: Jews in the Los Angeles Mosaic," in fews in the Los Angeles Mosaic, ed. Karen S. Wilson (Berkeley: University of California, Press, 2013), 3, 6-8. See also Phil Blazer and Shelley Portnoy, Wrestling with the Angels: A History of Jewish Los Angeles (Sherman Oaks, CA: Blazer Communications, 2006), 282-301.

${ }^{47}$ Christopher Koelsch, phone interview with the author, August 18, 2012. Michael Haas similarly writes, there is a risk-a "heffalump trap"-in the "re-ghettoization of Jewish composers": "Mirror-imaging Nazi policies in order to resurrect the composers they banned may be inevitable, but taking them from one ghetto and plunking them into another can be a real danger." Michael Haas, "Where to Start or How to Start? (Part 1)," The OREL Foundation, http://orelfoundation.org/index.php/journal/journalArticle/where to start_or how to_start/. Even the designation "Recovered Voices" has the potential to mark the included composers as other-separate-as they were segregated during the Nazi era. For that reason, in part, Conlon hopes ultimately to include his project's repertoire in regular concert programming, with no special branding as "project." That is, he hopes the music will take its rightful place, based solely on musical value, in standard musical literature, making the need for his program obsolete. James Conlon, interview with the author (Los Angeles, CA), October 8, 2012.

${ }^{48}$ Janos Gereben, "Conlon to Direct Jewish Music Project," San Francisco Classical Voice, http://www.sfcv.org/arts revs/music news 12 12 06.php.

${ }^{49}$ Naomi Pfefferman, "The Best of (Jewish) Los Angeles 2008," Fewish Observer, July 3, 2008.

${ }^{50}$ Marilyn Ziering, a Los Angeles-based philanthropist, it should be mentioned, does bring to the project a more prominent Jewish connection, with her sponsorship of the project, inspired by her father's love of opera and her late husband's survival in a concentration camp. In a "Q\&A" within the Santa Monica "Recovered Voices" concert program, she explained, "I believe that when someone writes something, part of the spirit of the person is in their work. If we bring back the compositions of these artists destroyed by the Nazis, we help to keep them alive." See "Q\&A with Marilyn Ziering," Program—Recovered Voices, Santa Monica, October 4, 2012: 42.

${ }^{51}$ Peter Novick, The Holocaust in American Life (Boston: Houghton Mifflin Company, 1999), 7. For some, this widely recognized means of identifying as Jewish through the Holocaust represents a trivialization of the Holocaust. See David M. Schiller, Bloch, Schoenberg, and Bernstein: Assimilating Fewish Music (New York: Oxford University Press, 2003$), 116$.

52 "What is Jewish Music?" Fewish Virtual Library, http://www.jewishvirtuallibrary.org/jsource/Society \& Culture/WhatIsJewishMusic.html.
} 
'authentically Jewish' music": "the pre-war, the holocaust related, or the Israeli." ${ }^{53}$ In scholarship as well, especially in Germany, we see this union between the Third Reich and Jewish music in the decades following the Holocaust. As musicologist Tina Frühauf demonstrates, most studies in German musical scholarship after World War II discuss Jewish music or musicians in "the context of Nazi Germany, the Holocaust, or in relationship to anti-Semitism. ${ }^{54}$ At the national meeting of the American Musicological Society in 2012, Florian Scheding similarly commented on the close relationship between Jewish music and Exilforschung (exile studies in Germany). He argued that discussion of the music of composers displaced after Hitler's assumption of power has become a proxy for investigating Jewish music. ${ }^{55}$ Jewish music for many is synonymous with music of Nazi persecution.

By bringing my discussion of the performance of suppressed music into this larger consideration of Jewish music, I hope to offer several final thoughts. This concertizing arises from positive intentions connected to rebirth, revival, and commemoration- "pious" perhaps. Still, like other efforts to effect constructive change through music, this area of performance is fraught with identity issues, perhaps the root of Saini's "discomfort" in Santa Monica, issues resulting from a complicated jumbling of history, music, and present self-identification through the past. With awareness of these competing layers, we in music can attend to the responsible handling of so-called suppressed music-and even work in scholarship as well as concert presentation to untangle, with an eye toward understanding, an increasingly confused popular merging of the Nazi era, Jewishness, and music. This call counters the evasion identified by David Engel in his book Historians of the Jews and the Holocaust, a decided division between Jewish studies and the history of the Holocaust based in part on academic concerns about the Holocaust's ability to divert "attention from how Jews themselves lived and what they created to the awful circumstances of their death. ${ }^{56}$ By confronting the popular discourse-a discourse that continues, and even intensifies, despite the stance of academics-I wonder if we can avoid future support or confirmation of the notion that all music with any relationship to the Holocaust is Jewish. This notion shrouds distinction within this repertoire, similar to the havoc wreaked by the term "Holocaust music." But it also fuels misleading imaginings of Jewish music today, a flame in turn fanned by the enduring problem of Jewish music in definition. Though a sign of evolution and even a sort of anti-essentialism (a new circumscription of Jewish music that is not based on ancestry or accepted ethnic musical markers), the idea that Jewish music is Holocaust-related to me still hearkens back to one-dimensional thinking that denies the complexities of the music involved. It also may support wider ossification of Jewish music as an entity of the past. As Philip Bohlman writes, "Jewish music in Europe today lives and relives through historicism. Since the reunification of Europe, no less than in the six decades or more since the Holocaust, Jewish music has increasingly come to function as a means of performing the past." ${ }^{257}$ In seeming contradiction, Jewish music thereby lives and changes in the present as a music of memorial, trauma, and ultimately negation.

\footnotetext{
${ }^{53}$ Jeff Janeczko, “A Tale of Four Diasporas: Case Studies on the Relevance of 'Diaspora' in Contemporary American Jewish Music," in Perspectives of Fewish Music: Secular and Sacred, ed. Jonathan L. Friedmann (Lanham, Maryland: Lexington Books, 2009), 31 .

${ }^{54}$ Given the delay in concentrated study in this area, Frühauf concludes, "It is through Germany's own history, its Nazi past, that musicologists ultimately found Jewish music.” Tina Frühauf, "Jewish Music and German Intellectual History, 19451989," in Displaced Memories: Fews, Music, and Postwar Culture, ed. Tina Frühauf and Lily E. Hirsch (New York: Oxford University Press, 2014).

${ }^{55}$ Florian Scheding, participant in the panel "Historiographies of Jewish Music Research," National Meeting of the American Musicological Society, November 2, 2012.

${ }^{56}$ David Engel, Historians of the Fews and the Holocaust (Stanford, CA: Stanford University Press, 2010), 30.

${ }^{57}$ Philip V. Bohlman, Fewish Music and Modernity (Oxford: Oxford University Press, 2008), 245.
} 
By raising this concern, it is not my goal to disparage the performance of suppressed music. Instead, I intend primarily to encourage discussion and, yes, criticism of concertizing in this realm. At a recent symposium entitled "Music, Censorship and Meaning in Nazi Germany and the Soviet Union: Echoes and Consequences" (Los Angeles, August 9-10, 2014), James Conlon expressed some concern about the effects of criticism on the dissemination of his recovered repertoire, suggesting that the public must first be allowed a "taste." There have in the past been much harsher reactions to criticism of works tied to trauma. For example, some who found manipulative John Corigliano's Symphony No. 1, which addresses the issue of AIDS, were labeled homophobes. ${ }^{58}$ In the controversial 1994 article "Discussing the Undiscussable," dance writer Arlene Croce, seemingly aware of such criticism, expressed her disapproval of personal trauma in art by commenting on her decision not to review Bill T. Jones's Still/Here, which explores AIDS in music, dance, and video. Frustrated by the privileging of self in this "victim art," Croce insisted, "By working dying people into his act, Jones is putting himself beyond the reach of criticism." We have seen similar sentiment in response to Leoffler, sentiment Loeffler himself foresaw ("it might seem like heresy to criticize ...”). It is not just the experience of the Holocaust that has then been viewed as unspeakable. Critical response to any expression of that experience has also been deemed inexpressible. Thomas Trezise has argued that belief in the Holocaust's unspeakability "appears to stand in for a refusal to listen." ${ }^{60}$ I would argue that any prohibition on discussion or criticism extends that refusal.

\begin{abstract}
Current performance of music denigrated during the Nazi era is remarkably vibrant, wide-ranging, and transnational. To date, however, there has been no in-depth scholarly intervention into any aspect of this work. Given the literature limitations as well as the unwieldy reach of the topic, this article is necessarily a starting point—an initial lookconfined to analysis of my collected data regarding the places, dates, and repertoire relevant to this realm of music making in the United States, despite its connections to similar work in other countries. This article also focuses on the impulse to effect constructive change bolstering such performance-the diverse, yet conceptually positive, goals that help explain the depth and breadth of concertizing devoted to music denigrated during the Nazi era.

And yet, as I explore, affirmative aims and aspirations are complicated by potential pitfalls, negative ramifications, as well as the ethics of Holocaust representation. By examining this opposition, this article contributes to a small, but growing, body of scholarship exposing the contradictions embedded in efforts to impact society constructively through music. Along these lines, I argue that performances dedicated to music persecuted during the Third Reich can promote a problematic conflation of Nazi-era composition and Jewish music, circumscribing all Holocaustrelated music as Jewish music.
\end{abstract}

\footnotetext{
${ }^{58}$ Tim Page, "Love the Art, Hate the Artist: Moral Questions are Unavoidable, but They Have No Answers," Washington Post, November 19, 1995.

${ }^{59}$ Arlene Croce, Writing in the Dark, Dancing in the New Yorker (New York: Farrar, Straus and Giroux, 2000), 709.

${ }^{60}$ Trezise, Witnessing Witnessing, 211.
} 